\title{
PENGARUH LAYANAN INFORMASI TERHADAP PEMAHAMAN SISWA PADA PENYALAHGUNAAN NARKOBA DI KELAS X DAN XI SMK SWASTA MAJU BINJAI TAHUN PELAJARAN 2016/2017
}

\author{
Nur Jannah' Azizah Batubara, Yulinda Dwinata \\ STKIP Budidaya Binjai
}

\begin{abstract}
Abstrak
Tujuan penelitian ini adalah untuk mengetahui seberapa besar pengaruh Layanan Informasi terhadap Pemahaman Siswa pada Penyalahgunaan Narkoba di Kelas X dan XI SMK Swasta Maju Binjai Tahun Pelajaran 2016/2017. Hipotesis penelitian ini adalah terdapat Pengaruh Layanan Informasi Terhadap Pemahaman Siswa pada Penyalahgunaan Narkoba di Kelas X dan XI SMK Swasta Maju Binjai Tahun Pelajaran 2016/2017. Analisis data yang digunakan dalam penelitian ini adalah analisis perbedaan dengan menggunakan rumus uji-t. Sebelum melakukan uji-t tanpa pembelajaran terlebih dahulu menghitung uji nomalitas dan homogenitas varians kedua kelompok sampel dengan tes kemampuan awal. Penelitian ini dilaksanakan di SMK Swasta Maju Binjai yang beralamat di Jalan Tengku Amir Hamzah Kelurahan Jati Makmur Kecamatan Binjai Utara Kode Pos 20746. Penelitian dilaksanakan pada semester ganjil tahun pelajaran 2016/2017. Berdasarkan hasil penelitian, dapat disimpulkan sebagai berikut: ada pengaruh layanan informasi dengan pemahaman siswa siswa kelas X dan XI SMK Swasta Maju Binjai tahun pelajaran 2016/2017. Dari tingkat Reliabilitas instrumen penelitian yang dibuat nilai Cronbach's Alpha 0,934 layanan informasi sementara tingkat Reliabilitas Instrumen penelitian yang dibuat nilai Cronbach's Alpha 0,928 pemahaman siswa pada penyalahgunaan narkoba. Perhitungan Adjusted $R$ Square 0,266. Hal ini berarti bahwa Standard Error of the Estimate 7,07839. Apabila variabel layanan informasi tidak ada. Hasil di atas memberikan penjelasan bahwa pemahaman siswa pada penyalahgunaan narkoba siswa meningkat apabila pengaruh layanan informasi lebih baik.
\end{abstract}

kata kunci: layanan informasi, pemahaman siswa, penyalahgunaan narkoba 


\section{PENDAHULUAN}

Menurut UU Nomor 20 tahun 2003, pendidikan adalah usaha sadar dan terencana untuk mewujudkan suasana belajar dan proses pembelajaran agar peserta didik secara aktif mengembangkan potensi dirinya untuk memiliki kekuatan spiritual keagamaan, pengendalian diri, kepribadian, kecerdasan, akhlak mulia, serta keterampilan yang diperlukan dirinya, masyarakat, bangsa dan Negara". Mempersiapkan masa depan terutama karir merupakan salah satu tugas remaja dalam tahap perkembangannya. Masa remaja adalah masa peralihan dari anak-anak ke dewasa. Sebagai individu yang sedang mengalami proses peralihan, remaja memiliki tugas-tugas perkembangan yang mengarah pada kesiapannya memenuhi tuntutan dan harapan peran sebagai orang dewasa.

Masa remaja adalah masa yang paling indah dalam periodisasi perkembangan manusia. Masa remaja membuat seorang anak merasakan indahnya kehidupan mulai dari memiliki banyak teman bergaul dan mengalami rasa jatuh cinta. Sri Rumini dan Siti Sundari mengatakan "masa remaja adalah masa peralihan dari masa anak dengan masa dewasa yang mengalami perkembangan semua aspek/fungsi untuk memasuki masa dewasa". Paparan Sri Rumini dan Siti Sundari dapat diartikan bahwa masa remaja adalah suatu masa yang menunjukkan posisi seorang individu berada dalam masa peralihan yaitu dari masa kanak-kanak menuju masa dewasa. Kebanyakan dari remaja adalah mereka yang berusia duduk di bangku sekolah menengah.

Fenomena yang terjadi bahwa rentannya remaja terjerumus dalam menyalahgunaan narkoba adalah dikarenakan remaja kurang mendapat informasi terhadap bahaya yang ditimbulkan akibat penyalahgunaan narkoba, pergaulan yang bebas sehingga mendekatkan diri mereka kepada narkoba.

Umumnya anak dan remaja menerima informasi tentang narkoba dari luar rumah, sebagian besar dari teman sebayanya. Sangat berbahaya ketika anak mengetahui suatu hal yang baru hanya setengah-setengah. Penulis katakan setengah-setengah karena biasanya anak hanya tau enaknya saja tidak mengerti dampak yang ditimbulkan akibat penyalahgunaan narkoba. Untuk itu orang tua perlu mengajarkan tentang narkoba secara detai kepada anak sehingga anak mengerti secara utuh dan mampu mengambil langkah yang benar. Penyalahgunaan narkoba dapat dicegah dan bahkan sebaiknya harus dicegah. Lebih baik mencegah dari pada mengobati, atau melakukan tindakan represif. Justru disinilah peran orang tua atau keluarga yang sangat penting dalam pencegahan penyalahgunaan narkoba pada anak.

Berdasarkan hasil wawancara peneliti dengan 10 orang siswa di SMK Swasta Maju Binjai, terungkap dari 10 orang siswa, hanya tiga orang siswa yang menyatakan mendapatkan 
informasi tentang bahaya yang ditimbulkan akibat penyalahgunaan narkoba, pergaulan yang bebas, lima orang siswa merasakan informasi tersebut membosankan, dan dua orang siswa menyatakan media yang digunakan oleh guru BK kurang menarik. Berdasarkan latar belakang yang telah dikemukakan terdahulu, maka dapat diidentifikasi sejumlah masalah-masalah yang berkaitan dengan persepsi siswa tentang informasi hasil penyalahgunaan narkoba diantaranya siswa menilai guru BK belum melaksanakan proses, menggunakan layanan informasi, menguasai materi informasi penyalahgunaan bahaya narkoba dengan optimal.

Faktanya bahwa informasi tentang bahaya narkoba di kalangan remaja akhir-akhir ini dirasakan sangat penting, mengingat banyaknya kasus tentang masalah narkoba di kalangan remaja. Hasil penelitian (Hawari) menyebutkan: (1) dark number=10, artinya 1 orang pecandu NAPZA jenis opiat (heroin, putaw) yang terdata terdapat 10 orang lainnya yang ada di masyarakat (tidak terdata); (2) angka kematian pada pecandu NAPZA jenis opiat (heroin, putaw) karena over dosis mencapai 17,16\%; (3) komplikasi medik pecandu NAPZA jenis opiate (heroin, putaw) berupa kelainan baru (bronchitis, brochopneumonia) 53,37\%, gangguan fungsi liver 55,10\%, dan hepatitis C 56,63\%; dan angka rawat inap ulang (kekambuhan) dari 2400 pecandu NAPZA jenis opiat (heroin, putaw) selama 2 tahun tercatat yang kambuh 293 atau $12,21 \%$.

Berdasarkan data dari Badan Narkotika Nasional tahun 2010, jumlah pengguna narkotika dan psikotropika pada usia sekolah menengah pertama sebanyak 6.859 orang, usia sekolah menengah atas sebanyak 14.986 orang, dan usia perguruan tinggi sebanyak 975 orang. Hal tersebut mengindikasikan bahwa remaja indonesia telah banyak yang menyalahgunakan napza untuk kepentingan kesenangan atau mencari kenikmatan semata.

NAPZA merupakan jenis obat-obatan yang sering digunakan dalam praktik dunia medis. Menurut Lydia Harlina Martono dan Satya Joewana menyatakan "Napza adalah istilah kedokteran untuk sekelompok zat yang jika masuk ke dalam tubuh menyebabkan ketergantungan (adiktif) dan berpengaruh pada kerja otak (psikoaktif)". Hal tersebut berarti bahwa napza merupakan zat yang sangat berbahaya bila masuk dalam tubuh manusia. Sebab napza dapat menyebabkan seseorang menjadi ketergantungan serta mempengaruhi kerja otak. Istilah umum yang ada dimasyarakat dan penegak hukum adalah narkoba yang memiliki arti narkotik, psikotropika dan obat terlarang. Hal tersebut berarti bahwa istilah NAPZA atau narkoba memiliki maksud yang sama yaitu keduanya merupakan obat-obatan yang berbahaya dan terlarang apabila digunakan secara illegal atau tanpa resep dokter.

Sebagai upaya preventif, pemberian penyuluhan tentang bahaya penyalahgunaan NAPZA dapat dilakukan di rumah, di sekolah maupun di masyarakat. Salah satu contoh dalam 
memberikan penyuluhan tersebut dapat dilakukan melalui pemberian layanan informasi. Ifdil menyatakan "layanan informasi adalah penyampaian berbagai informasi kepada sasaran layanan agar individu dapat menolah dan memanfaatkan informasi tersebut demi kepentingan hidup dan perkembangannya". Hal tersebut berarti bahwa layanan informasi merupakan suatu bentuk kegiatan atau usaha yang dilakukan oleh seorang informan terhadap sekelompok orang yang menerima informasi mengenai berbagai macam pengetahuan. Layanan informasi yang diberikan secara umum bertujuan agar terkuasainya informasi tertentu. Sedangkan secara khusus agar paham terhadap informasi yang diberikan dan memanfaatkan informasi dalam penyelesaian masalahnya.

Layanan informasi yaitu layanan Bimbingan dan Konseling yang memungkinkan peserta didik (klien) menerima dan memahami berbagai informasi yang dapat digunakan sebagai bahan pertimbangan dan pengambilan keputusan untuk kepentingan peserta didik. Klien tidak hanya peserta didik tetapi bisa juga orang tua atau wali. Menurut Prayitno \& Erman Amti mengatakan bahwa layanan informasi adalah kegiatan memberikan pemahaman kepada individu-individu yang berkepentingan tentang berbagai hal yang diperlukan untuk menjalani suatu tugas atau kegiatan, atau untuk menentukan arah suatu tujuan atau rencana yang dikehendaki. Dengan demikian, layanan informasi itu pertama-tama merupakan perwujudan dari fungsi pemahaman dalam bimbingan dan konseling.

Berdasarkan latar belakang di atas, maka peneliti ingin melakukan penelitian dengan judul "Pengaruh Layanan Informasi Terhadap Pemahaman Siswa pada Penyalahgunaan Narkoba di kelas X dan XI SMK Swasta Maju Binjai tahun pelajaran 2016/2017”.

\section{Pengertian Narkoba}

Menurut Kurniawan, "Narkoba adalah zat kimia yang dapat mengubah keadaan psikologi seperti perasaan, pikiran, suasana hati serta perilaku jika masuk ke dalam tubuh manusia baik dengan cara dimakan, diminum, dihirup, suntik, intravena, dan lain sebagainya".

\section{Ciri-ciri Narkoba yang Dikonsumsi}

Seseorang yang menggunakan narkoba dapat terlihat dari ciri-ciri yang terlihat pada dirinya seperti berikut ini: (1). Pecandu putaw, (2). Pecandu daun ganja, (3). Pecandu sabusabu dan (4). Pecandu Inex atau ekstasi.

\section{Jenis-jenis Narkoba}

Ada berbagai jenis-jenis narkoba diantaranya, morfin yaitu morfin adalah hasil olahan dari opium/candu mentah, Codein yaitu yaitu Codein termasuk garam turunan dari opium dan candu, Heroin (putaw) yaitu Heroin mempunyai kekuatan yang dua kali lebih kuat dari morfin, Methadon yaitu Methadone banyak digunakan orang dalam pengobatan ketergantungan opioid, 
Demerol yaitu Nama lain dari Demerol adalah pethidina. Pemakaiannya dapat ditelan atau dengan suntikan, dan Candu yaitu Getah tanaman Papaver Somniferum didapat dengan menyadap (menggores) buah yang hendak masak. Getah yang keluar berwarna putih dan dinamai "Lates". Macam-macam Narkotika yaitu (1) Opioid, (2) Kokain, (3) Cannabis/ganja, (4) Psikotropika.

\section{Pencegahan}

Mencegah peredaran narkoba dengan melindungi masyarakat dan orang tua kita harus melindungi dan mengajarkan anaknya dengan baik. Prinsipnya dengan meningkatkan peranan atau kegiatan agar kelompok ini secara lebih nyata sejahtera. Selama ini BNN telah merancang kegiatan untuk mencegah : Promotif yang di tunjukkan kepada masyarakat yang belum memakai narkoba, atau bahkan belum mengenal sama sekali. Preventif melalui kampanye anti penyalahgunaan narkoba, penyuluhan seluk beluk tentang narkoba, dan pelatihan kelompok sebaya dan pendidikan. Advokasi bentuk rangkaian komunikasi strategis yang di rancang secara sistematis dan dilaksanakan dalam kurun waktu tertentu. KIE bentuk komunikasi yang di laksanakan oleh provider program agar sasaran menerima program yang di tawarkan.

\section{Layanan Informasi}

\section{Pengertian Layanan Informasi}

Layanan informasi yaitu : layanan Bimbingan dan Konseling yang memungkinkan peserta didik (klien) menerima dan memahami berbagai informasi (seperti informasi pendidikan dan informasi jabatan) yang dapat digunakan sebagai bahan pertimbangan dan pengambilan keputusan untuk kepentingan peserta didik (klien). Klien tidak hanya peserta didik tetapi bisa juga orang tua atau wali.

\section{Tujuan dan Fungsi Layanan Informasi}

\section{Tujuan Layanan Informasi}

Layanan informasi bertujuan untuk membekali individu dengan berbagi pengetahuan dan pemahaman tentang berbagai hal yang berguna untuk mengenal diri, merencanakan, dan mengembagkan pola kehidupan sebagai pelajar, anggota keluarga dan masyarakat. Pemahaman yang diperoleh melalui layanan informasi, digunakan sebagai bahan acuan dalam meningkatkan kegiatan dan prestasi belajar, mengembangkan cita-cita, menyelenggarakan kehidupan sehari-hari dalam mengambil sebuah keputusan.

\section{Fungsi Layanan Informasi tentang Penyalahgunaan Narkoba}

Agar siswa mampu mengetahui tentang penyalahgunaan narkoba, bahaya narkoba, dan penyakit-penyakit yang ditimbulkan karena penggunaan narkoba.

\section{Cara Pencegahan Penyalahgunaan Narkoba}


Penyalahgunaan narkoba dapat dicegah dan bahkan sebaiknya harus dicegah. Lebih baik mencegah dari pada mengobati, atau melakukan tindakan represif. Justru disinilah peran orang tua atau keluarga yang sangat penting dalam pencegahan penyalahgunaan narkoba pada anak. Berikut ini ada beberapa langkah yang dapat dilakukan orang tua untuk mengurangi penyalahgunaan narkoba.

\section{Mempelajari Masalah Narkoba}

Tidak mungkin anda mencegah, jika Anda tidak tahu apa yang sedang anda coba untuk mencegahnya. Ambillah kesempatan untuk mempelajari masalah narkoba. Dengan membaca, mendengarkan ceramah, berdiskusi, dan membahas masalah narkoba di majalah, koran, atau pada program televisi dan radio. Anda harus mengerti jenis-jenis narkoba dan bahaya menggunakan narkoba yang nantinya kita akan sampaikan kepada anak kita sebagai proses pendidikan tentang narkoba.

\section{Mengajarkan Anak tentang Masalah Narkoba}

Umumnya anak dan remaja menerima informasi tentang narkoba dari luar rumah, sebagian besar dari teman sebayanya. Sangat berbahaya ketika anak mengetahui suatu hal yang baru hanya setengah-setengah. Saya katakan setengah-setengah karena biasanya anak hanya tau enaknya saja tidak mengerti dampak yang ditimbulkan akibat penyalahgunaan narkoba Untuk itu orang tua perlu mengajarkan tentang narkoba secara detai kepada anak sehingga anak mengerti secara utuh dan mampu mengambil langkah yang benar.

\section{Penyakit Yang Ditimbulkan Akibat Penyalahan Narkoba}

Penyakit berbahaya sebagai akibat dari penyalahgunaan narkoba dapat dibedakan atas 3 kelompok yaitu penyakit langsung karena narkoba, penyakit akibat infeksi, karena cara pemakaian narkoba, dan penyakit sebagai akibat tidak langsung dari pemakaian narkoba. Penyakit akibat penyalahgunaan narkoba yang lain adalah penyakit infeksi berbahaya, seperti HIV/AIDS, Hepatitis, dan Sipilis. Penyakit sebagai akibat Ikutan (tidak langsung) pemakaian narkoba.

\section{Materi Umum Layanan Informasi}

Materi yang dapat yang diangkat melalui layanan informasi ada berbagai macam, yaitu meliputi:

1. Informasi pengembangan pribadi

2. Informasi kurikulum dan proses belajar mengajar

3. Informasi jabatan 
4. Informasi kehidupan keluarga, sosial kemasyarakatan, keberagaman, sosial budaya, dan lingkungan

5. Informasi pendidikan tinggi

\section{METODE PENELITIAN}

Penelitian dilaksanakan di SMK Swasta Maju Binjai, beralamat di Jalan Tengku Amir Hamzah Kelurahan Jati Makmur Kecamatan Binjai Utara Kota Binjai. Penelitian dilaksanakan pada semester ganjil tahun pelajaran 2016/2017.

Peneliti akan menggunakan pendekatan eksperimen, untuk menjelaskan dan meringkas hubungan antara dua variabel yaitu variabel devenden dan variabel devendent. Lebih lanjut Sukmadinata menyatakan bahwa "variabel indevendent atau variabel yang mempengaruhi berfungsi untuk memprediksi besar kecilnya nilai variabel indevendent. Sedangkan variabel dependen adalah variabel yang dipengaruhi atau yang diramalkan". Dalam penelitian ini variabel devenden adalah layanan informasi dan variabel indevendent adalah pemahaman siswa pada penyalahgunaan narkoba.

Populasi dalam penelitian ini adalah seluruh siswa kelas X dan kelas XI SMK Swasta Maju Binjai yang terdiri dari 2 kelas dengan masing-masing kelas 32 siswa. Jumlah populasi dalam penelitian ini berjumlah 64 siswa.

Arikunto memberikan pendapat sebagai berikut: “....jika peneliti memiliki beberapa ratus subjek dalam populasi, maka mareka dapat menentukan kurang lebih 25-30\% dari jumlah tersebut. Jika jumlah anggota subjek dalam populasi hanya meliputi antara 100-150 orang, dan dalam pengumpulan datanya peneliti menggunakan skala, maka sebaiknya subjek sejumlah itu diambil seluruhnya. Dikarenakan jumlah populasi dalam penelitian ini kurang dari 100, maka penelitian ini adalah penelitian populasi dengan sampel penelitian 64 siswa.

Instrumen yang digunakan dalam penelitian ini berupa angket yaitu untuk mengukur variabel pemahaman siswa dan layanan informasi. Angket yang digunakan adalah angket tertutup, karena responden tinggal memilih jawaban yang telah tersedia dan diharapkan responden memilih jawaban yang sesuai dengan keadaan yang sebenarnya.

Reliabilitas adalah sesuatu instrumen cukup dapat dipercaya untuk digunakan sebagai alat pengumpul data karena instrumen tersebut sudah baik. Pada penelitian ini untuk mencari reliabilitas instrumen menggunakan rumus alpha $\boldsymbol{\alpha}$, karena instrumen dalam penelitian ini berbentuk angket atau daftar pertanyaan yang skornya merupakan rentangan antara 1-5 dan uji validitas menggunakan item total, dimana untuk mencari reliabilitas instrumen yang skornya bukan 1 dan 0 , misalnya angket atau soal bentuk uraian maka menggunakan rumus 
alpha $\boldsymbol{\alpha}$ : Reliabilitas adalah sejauh mana hasil suatu pengukuran dapat dipercaya, maksudnya apabila dalam beberapa pelaksanaan pengukuran terhadap kelompok yang sama diperoleh hasil yang relatif sama. Dalam penelitian ini, uji reliabilitas dilakukan dengan menggunakan tekhnik Formula Alpha Cronbach dan dengan menggunakan program SPSS 19.0 for Windows.

Validitas adalah suatu ukuran yang menunjukkan tingkat-tingkat kevalidan atau Maksudnya butir-butir soal disusun sesuai materi dan indikator pembelajaran. Untuk menguji validitas test, penulis menggunakan rumus korelasi product moment, yaitu :

$$
r_{x y}=\frac{N \sum X Y-\left(\sum X\right)\left(\sum Y\right)}{\sqrt{\left\{N \sum X^{2}-\left(\sum X\right)^{2}\right\}\left\{N \sum Y^{2}-\left(\sum Y\right)^{2}\right\}}}
$$

Dimana :

$$
\begin{array}{ll}
\text { rxy } & =\text { Koefisien korelasi antara variabel X dan variabel } \mathrm{Y} \\
\mathrm{N} & =\text { Jumlah sampel } \\
\mathrm{X} & =\text { Nomor soal (Butir Soal) } \\
\mathrm{Y} & =\text { Total Skor }
\end{array}
$$

Uji reliabilitas menyangkut ketetapan alat ukur, apakah suatu alat ukur sudah cukup akurat, stabil dan konsisten dalam mengukur apa yang ingin diukur. Uji reliabilitas digunakan untuk melihat kestabilan dan konsistensi dari siswa dalam menjawab hal yang berkaitan dengan pertanyaan yang disusun dalam suatu bentuk kuesioner. Hasil uji ini mencerminkan dapat atau tidaknya dipercaya suatu instrumen penelitian, berdasarkan tingkat ketepatan dan kemantapan suatu alat ukur. Alat uji yang digunakan adalah table Alpha Cronbach.

Analisis data dilakukan dengan tujuan agar data yang telah diperoleh akan lebih bermakna. Melakukan analisis merupakan pekerjaan yang sulit di dalam sebuah penelitian dan memerlukan kerja keras, kesungguhan dan keseriusan. Analisis memerlukan daya kreatifitas serta kemampuan yang baik. Analisis memerlukan suatu proses menyusun data agar diinterprestasikan dan lebih bermakna. Sebelum menganalisa data-data yang dikumpulkan, maka dilakukan uji asumsi, yang terdiri dari:

1. Uji normalitas bertujuan untuk melihat apakah sampel yang digunakan dalam penelitian terdistribusi normal atau tidak. Uji normalitas ini dilakukan dengan menggunakan uji onesample Kolmogorov-Smirnov dengan bantuan SPSS for Windows Versi 19.0. Data dikatakan terdistribusi normal jika nilai $\mathrm{p}>0,05$.

2. Uji homogenitas dilakukan untuk mengetahui apakah sampel yang diambil varians homogen atau tidak, Dengan kriteria pengujian : terima hipotesis kerja jika data berasal 
dari populasi yang homogen jika $\mathrm{F}>\mathrm{F}_{\alpha\left(\mathrm{n}_{1}{ }^{\left.-1, \mathrm{n}_{2}-1\right)}\right.}$ dalam perhitungan dari daftar distribusi F dengan $\alpha=0,05$. Disini $\alpha$ adalah taraf nyata untuk pengujian.

3. Untuk menentukan adanya peningkatan pemberian perlakuan layanan informasi terhadap pemahaman siswa dilihat dari ada tidaknya perbedaan hasil postes siswa pada kedua kelas yaitu kelas eksperimen dan kelas kontrol. Pengujian ada tidaknya perbedaan hasil postes siswa digunakan uji t satu pihak. Kriteria pengujian adalah tolak hipotesis kerja jika $t<t_{1-\alpha}$ dan terima hipotesis jika t mempunyai harga-harga lain. Derajat kebebasan untuk distribusi t dengan $\mathrm{dk}=\left(\mathrm{n}_{1}+\mathrm{n}_{2}-2\right)$ dan peluang $(1-\alpha)$.

\section{HASIL DAN PEMBAHASAN}

Seperti penelitian yang dilakukan oleh Anita Juniarti dengan judul skripsi "Pengaruh Layanan Informasi terhadap motivasi kerja guru di MAN Malang II Batu tahun 2010” Hasil pengujian hipotesis dengan menggunakan teknik regresi linier berganda bahwa sumbangan efektif penelitian sebesar $(0,728 \times 100 \%=72,8 \%)$ yang artinya $72,8 \%$ motivasi kerja guru dipengaruhi oleh gaya kepemimpinan kepala sekolah, sedangkan sisanya yaitu 27,2\% dipengaruhi oleh faktor lain diluar pembahasan dari penelitian ini. Dan berdasarkan data yang terkumpul dan analisis didapatkan hasil yang signifikan (44,662 dengan signifikansi sebesar $0,000<0,05)$ artinya semakin tinggi gaya kepemimpinan, maka motivasi kerja semakin baik.

Penelitian yang dilakukan dengan menyebar angket (Quisioner) kepada siswa SMK Swasta Maju Binjai. Total jumlah responden sebanyak 64 siswa. Dalam penelitian ini yang digunakan adalah menyebar angket (Quisioner) pada siswa SMK Swasta Maju Binjai sebagai sampel (responden) sebanyak 64 siswa dengan 4 item pernyataan. Untuk pemahaman siswa pada penyalahgunaan narkoba terdiri dari 40 pernyataan dan layanan informasi 40 pernyataan. Hasil penelitian yang diperoleh dari hitungan statistik, didapat bahwa ada pengaruh layanan informasi dengan pemahaman siswa pada penyalahgunaan narkoba siswa kelas X dan XI SMK Swasta Maju Binjai Tahun Pelajaran 2016/2017. Dari Tingkat Reliabilitas Instrumen Penelitian yang dibuat nilai Cronbach's Alpha 0,932 layanan informasi sementara tingkat Reliabilitas Instrumen Penelitian yang dibuat nilai Cronbach's Alpha 0,925 pemahaman siswa. Perhitungan Adjusted R Square 0,266. Hal ini berarti bahwa Standard Error of the Estimate 7,07839. Apabila variabel layanan informasi tidak ada. Hasil di atas memberikan penjelasan pemahaman siswa pada penyalahgunaan narkoba meningkat apabila pengaruh layanan informasi lebih baik. 
Artinya bahwa pada penelitian terdahulu dan penelitian yang dilakukan sekarang menunjukkan benar bahwa terdapat pengaruh layanan informasi dengan pemahaman siswa pada penyalahgunaan narkoba kelas X dan XI SMK Swasta Maju Binjai Tahun Pelajaran 2016/2017.

Berdasarkan hasil penelitian, dapat disimpulkan sebagai berikut: ada pengaruh layanan informasi dengan pemahaman siswa siswa kelas X dan XI SMK Swasta Maju Binjai tahun pelajaran 2016/2017. Dari tingkat Reliabilitas instrumen penelitian yang dibuat nilai Cronbach's Alpha 0,934 layanan informasi sementara tingkat Reliabilitas Instrumen penelitian yang dibuat nilai Cronbach's Alpha 0,928 pemahaman siswa pada penyalahgunaan narkoba. Perhitungan Adjusted $R$ Square 0,266. Hal ini berarti bahwa Standard Error of the Estimate 7,07839. Apabila variabel layanan informasi tidak ada. Hasil di atas memberikan penjelasan bahwa pemahaman siswa pada penyalahgunaan narkoba siswa meningkat apabila pengaruh layanan informasi lebih baik.

\section{KESIMPULAN}

Berdasarkan pembahasan dan kesimpulan hasil penelitian di atas, maka peneliti memiliki beberapa saran antara lain:

1. Bagi mahasiswa calon guru yang ingin memberikan layanan informasi diharapkan lebih memahami layanan informasi dan memperhatikan penggunaan alokasi waktu yang tepat sesuai materi pokok yang akan diajarkan.

2. Bagi peneliti selanjutnya yang ingin meneliti tentang layanan informasi lebih lanjut, disarankan agar alat yang dibutuhkan ditinjau dari segi jumlah maupun kualitas cukup baik sehingga aktivitas siswa dalam percobaan berjalan lancar.

3. Bagi peneliti selanjutnya yang ingin meneliti tentang layanan informasi diharapkan mampu mengelola kelas dengan baik sehingga pembelajaran yang efektif dapat tercapai.

\section{DAFTAR PUSTAKA}

Arikunto, Suharsimi. 2002. Prosedur Penelitian Suatu Pendekatan Praktik. Jakarta: Rineka Cipta. 2008. Dasar-Dasar Evaluasi Pendidikan. Jakarta: Bumi Aksara.

Azwar, Syaifuddin. 2000. Statistika Untuk Penelitian, Sebelas Maret University Press, Surakarta. 
Ghoodse. 2002. Implementasi Bimbingan dan Konseling di Sekolah. Jakarta: Sumber Ilmu.

Hermawan, Asep. 2005. Penelitian Bisnis: Paradigma Kuantitatif. Jakarta: Grasindo.

Ifdil. 2008. Layanan Bimbingan dan Konseling. Surabaya: Unesa Universitas Unesa.

Jackobus. 2005. Psikologi perkembangan peserta didik. Jakarta: Rineka Ilmu.

Kurniawan. 2009. Bimbingan Karir untuk SMK. Jakarta: Intan Pariwara.

Margono. 2010. Metodologi Penelitian Pendidikan. Jakarta: Rineka Cipta.

Mulyana, Dedi. 2005. Ilmu Komunikasi: Suatu Pengantar. Bandung: Remaja Rosdakarya.

Undang-undang Republik Indonesia No 20 Tahun, 2003 tentang Sistem Pendidikan Nasional. Jakarta: DPR RI.

Purwoko, Budi. 2008. Organisasi dan Managemen Bimbingan Konseling. Surabaya: Unesa University Press.

Prayitno. 2004. Dasar-dasar Bimbingan dan Konseling. Jakarta: Rineka Cipta.

Prayitno \& Erman Amti. 2004. Dasar-Dasar BK. Jakarta: Rineka Cipta.

Rumini, Sri dan Siti Sundari. 2004. Remaja dalam persfektif Globalisasi. Jakarta: Rineka Cipta.

Sugiyono. 2013.Statistik Untuk Penelitian. Bandung: CV. Alfabeta.

Sukmadinata, Nana Syaodih. 2010. Metode Penelitian Pendidikan, Bandung: PT. Remaja Rosdakarya.

Supatra, I Made. 2004. Perkembangan Anak. Jakarta: Sumber Ilmu.

Winkel \& Sri Hastuti. 2006. Bimbingan dan Konseling di Institusi Pendidikan. Yogjakarta: Media Abadi.

Wresniwiro. 2008. Bahaya narkoba bagi generasi penerus bangsa. Surabaya: Sumber Karya Ilmu. 